\title{
5-METHYLCOUMARIN DERIVATIVES FROM APHYLLOCLADUS DENTICULATUS
}

\author{
C. Zdero, F. BohlmanN and H. M. NiemeyeR*
}

Institute of Organic Chemistry, Technical University of Berlin, D-1000 Berlin 12, F. R. G.; *Facultad de Ciencias, Universidad de Chile, Casilla 653, Santiago, Chile

(Received 28 October, 1987)

Key Word Index-- Aphyllocladus denticulatus var. denticulatus; Compositae; 5-methylcoumarin derivatives; sesquiterpenes.

Abstract-The aerial parts of Aphyllocladus denticulatus afforded, in addition to some widespread compounds, six 5methylcoumarin derivatives isolated previously from a Lycoseris species, and eight new ones. The structures were elucidated by high field NMR techniques. The chemotaxonomic relevance of the results is briefly discussed.

\section{INTRODUCTION}

The small genus Aphyllocladus (Compositae, tribe Mutisieae), distributed in the Andes from S Bolivia to N Chile, has been placed in the subtribe Gochnatiinae [1]. So far, no reports have been produced on its chemistry. As a continuation of our investigations of the tribe Mutisieae, we have studied $A$. denticulatus (Remy) Cabr. var. denticulatus.

\section{RESULTS AND DISCUSSION}

The extract of the aerial parts afforded, in addition to widespread compounds (see Experimental), the known 5methylcoumarin derivatives 1 [2], 6 [2], 8 [2], 10 [2], 12 [2] and 13 [2], as well as eight further ones, the hydroxylycoserin 2, which was isolated as its acetate $2 \mathbf{a}$, an isomer named isolycoserone (3) and its $10^{\prime}$-hydroxy derivative $\mathbf{4}$, the $1^{\prime}, 2^{\prime}, 6^{\prime}, 7^{\prime}, 8^{\prime}$-epimer of $8(5)$, a $10^{\prime}, 11^{\prime}$-dehydro derivative of 8 (7), a 10-hydroxy derivative of $8(9)$, the nor compound 11 named aphyllocladone, and the partly rearranged nor derivative 14 named aphyllodenticulide.

The structure of 2 followed from the ${ }^{1} \mathbf{H}$ NMR data of the corresponding acetate $\mathbf{2 a}$ (Table 1 ) which were similar to those of the corresponding $10^{\prime}$-desoxy derivative [2]. Spin decoupling indicated that the doublet at $\delta 5.61$ was the $\mathrm{H}-10^{\prime}$ signal. Accordingly, the additional oxygen function was at $\mathrm{C}-10^{\prime}$.

The ${ }^{1} \mathrm{H}$ NMR spectral data of 3,4 and the corresponding acetate $4 a$ (Table 1) were similar. Spin decoupling showed that in coumarin 4 an oxygen function at C-10' was present. Furthermore, a broadened singlet around $\delta 1.5(3 \mathrm{H})$ indicated an olefinic methyl group. The down field shift of H-5' showed, in agreement with the mass spectrum, the presence of a $8^{\prime}$-keto group. A pair of doublets with a large geminal coupling in the spectra of all three compounds around $\delta 2.9$ was assigned to $\mathrm{H}-1^{\prime}$. This was supported by the MS which showed the fragments $189\left(\mathrm{C}_{14} \mathrm{H}_{9} \mathrm{O}_{3}\right)$, and $222\left(\mathrm{C}_{14} \mathrm{H}_{22} \mathrm{O}_{2}\right)$ indicating a preferred splitting of the $1^{\prime}, 2^{\prime}$-bond. In the MS of 4 elimination of $\mathrm{Me}_{2} \mathrm{CHCHO}(m / z$ 354) was visible. Inspection of a model led to the proposal that a hydrogen bond between the $10^{\prime}$-hydroxyl and the $8^{\prime}$-keto group may be present. This as well as the whole stereochemistry was established by the observed NOEs. Thus clear effects were present between $\mathrm{H}-10^{\prime}, \mathrm{H}-3^{\prime}, \mathrm{H}-11^{\prime}$ and $\mathrm{H}-12^{\prime}$, between $\mathrm{H}-9$ and $\mathrm{H}-6$, between $\mathrm{H}-15^{\prime}$ and $\mathrm{H}-\mathrm{-}^{\prime}$ as well as between $\mathrm{H}-13^{\prime}$ and $\mathrm{H}-9$. The resulting configurations of $\mathrm{C}-2^{\prime}, \mathrm{C}-3^{\prime}$ and $\mathrm{C}-9^{\prime}$ are the same in compound 3 , as indicated by the similarity of the ${ }^{1} \mathrm{H}$ NMR signals. The ${ }^{13} \mathrm{C}$ NMR data of 4 also supported the structure. INEPT experiments were necessary for the complete assignment. Compound 3 has been named isolycoserone.

The ${ }^{1} \mathrm{H}$ NMR spectrum of $4 \mathrm{a}$ at room temperature was highly broadened indicating a mixture of conformers most likely due to restricted rotation. At elevated temperature clcar signals were observed which allowed spin decoupling.

The ${ }^{1}$ HNMR spectrum of 5 (Table 1) was in part similar to that of cyclolycoserone (8) [2]. However, some chemical shifts differed and the optical rotation had the opposite sign. The observed NOEs indicated that the configurations of $\mathrm{C}-1^{\prime}, \mathrm{C}-2^{\prime}, \mathrm{C}-6^{\prime}, \mathrm{C}-7^{\prime}$ and $\mathrm{C}-8^{\prime}$ were reversed but not that of $\mathrm{C}-3^{\prime}$. Thus, clear effects were observed between $\mathrm{H}-14^{\prime}, \mathrm{H}-6^{\prime}, \mathrm{H}-9$ and $\mathrm{H}-7^{\prime}$, between $\mathrm{H}-15^{\prime}, \mathrm{H}-7^{\prime}, \mathrm{H}-\mathrm{I}^{\prime}$ and $\mathrm{H}-3^{\prime}$, between $\mathrm{H}-6^{\prime}, \mathrm{H}-14^{\prime}$ and $\mathrm{H}-2^{\prime}$, as well as between $\mathrm{H}-7^{\prime}, \mathrm{H}-14^{\prime}$ and $\mathrm{H}-15^{\prime}$. The stereochemistry agrees with the results of a chiral synthesis of lycoserone, cyclolycoserone and also of the epimer 5 [3]. Therefore, the absolute configuration of these compounds could also be established.

The ${ }^{1}$ H NMR data of 7 (Table 1) were similar to those of cyclolycoserone [2]. The presence of a $10^{\prime}, 11^{\prime}$-double bond followed from its typical signals $[\delta 6.45 q q, 2.24 d$ $(3 \mathrm{H}), 1.99 d(3 \mathrm{H})]$. Similarly, the spectrum of 9 pointed to a $10^{\prime}$-hydroxy derivative of 8 . Thus, an additional low field signal at $\delta 4.81$ was observed which showed a $7 \mathrm{~Hz}$ coupling with a signal at $\delta 2.13 d$ (hydroxy proton). Most likely, a hydrogen bond between the hydroxy group and an ether oxygen was present. However, the relative configuration at $\mathrm{C}-10^{\prime}$ could not be assigned.

Compounds 12 and 13 were isolated previously as a mixture [2]. After acetylation, the corresponding acetates $12 a$ and 13a could be separated by repeated TLC.

The ${ }^{1}$ H NMR data (Table 1) and the molecular formula of 11 indicated that most likely a benzofuran de- 


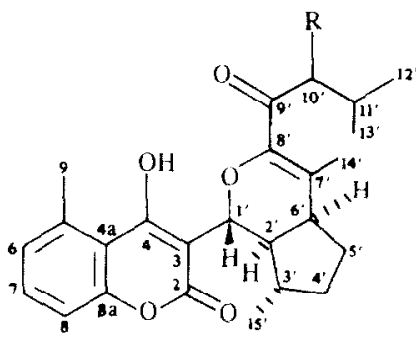

$1 \quad \mathrm{R}=\mathrm{H}\left(\mathbf{1}^{\prime \prime}-\mathrm{ep} i\right)$

$2 \mathrm{R}=\mathrm{OH}$

2a $\mathbf{R}=\mathrm{OAC}$

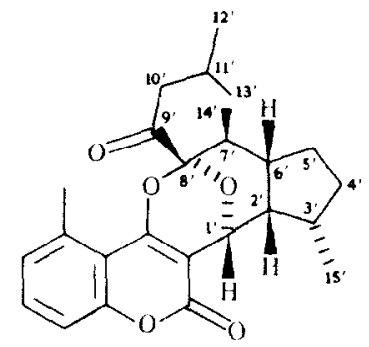

5

$6 \quad 6.7$ epoxide<smiles>Cc1cccc(O)c1C(=O)C[C@]1(C)OC2=C(CC(C)CC2=O)[C@H]2CC[C@@H](C)[C@H]21</smiles>

10

rivative was present. In agreement with this proposal the signals of the aromatic protons were shifted up field. Spin decoupling further showed that the sequence $\mathrm{H}-\mathrm{1}^{\prime}$ to $\mathrm{H}-6^{\prime}$ was identical with that of 12 . The nature of the side chain at $\mathrm{C} \cdot \mathrm{8}^{\prime}$ followed from the typical senecioyl signals. The configurations of $\mathrm{C}-7^{\prime}$ could not be assigned. Most likely ketone 11 is closely related to 12 . If the $7^{\prime}, 8^{\prime}$-epoxide of the 2-desoxy derivative of $10^{\prime}, 11^{\prime}$-dehydro 12 were assumed as a precursor, the corresponding enol of the 3keto group could open the epoxide by formation of the proposed ketal. Ketone $\mathbf{1 1}$ has been named aphyllocladone.

The structure of $\mathbf{1 4}$ was deduced from the molecular formula $\left(\mathrm{C}_{20} \mathrm{H}_{20} \mathrm{O}_{5}\right)$ and the ${ }^{1} \mathrm{H}$ NMR spectrum (Table 1). Spin decoupling gave the sequence $H-l^{\prime}$ to $H-6^{\prime}$ and the position of the secondary methyl $(\mathrm{H}-15)$. The chemical shift of the methyl singlet $(\delta 1.79)$ required several deshielding effects which are present only at the proposed carbon. The presence of a lactone followed from the IR band at $1760 \mathrm{~cm}^{-1}$ and by INEPT of $\mathrm{H}-14^{\prime}$ with $\mathrm{C}-7^{\prime}$ and the carbonyl carbon as well as of $\mathrm{H}-\mathrm{l}^{\prime}$ with the latter. The observed NOEs supported the structure and allowed the
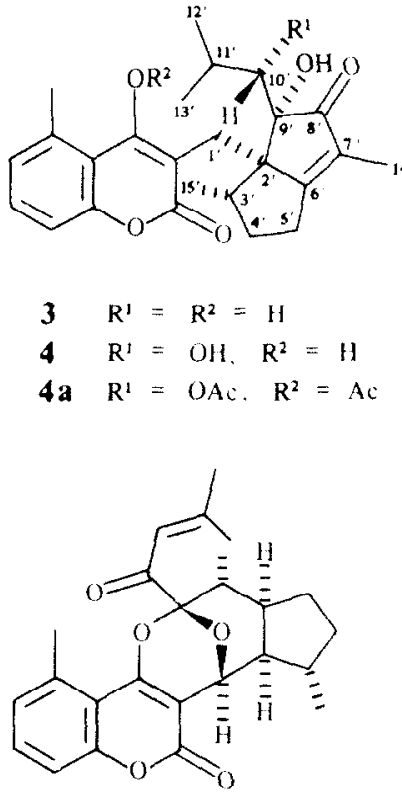

7

$810.11 \mathrm{H}$

9 10- OH: 10.1111

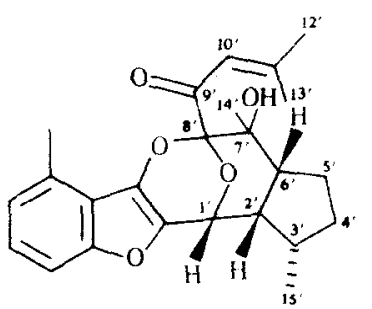

11

assignment of the stereochemistry. Thus, clear effects were present between $\mathrm{H}-15^{\prime}$ and $\mathrm{H}^{-1} \mathbf{1}^{\prime}$, between $\mathrm{H}-14^{\prime}, \mathrm{H}-$ $6^{\prime}$ and $\mathrm{H}-9$, between $\mathrm{H}-3^{\prime}$ and $\mathrm{H}-2^{\prime}$, between $\mathrm{H}-9, \mathrm{H}-14$ and $\mathrm{H}_{-} \mathbf{6}^{\prime}$, between $\mathrm{H}-2^{\prime}, \mathrm{H}-3^{\prime}, \mathrm{H}-\mathbf{6}^{\prime}$ and $\mathrm{H}_{-} \mathbf{1}^{\prime}$, as well as between $H-6^{\prime}$ and $H-2^{\prime}$. The ketone 14, which has been named aphyllodenticulide, is most likely formed via the proposcd prccursor epoxide 15 , by isomerization and oxidative cleavage of the diketone 16 (see Scheme). The structure was established by synthesis [3].

The isolation of the 5-methylcoumarins is of chemotaxonomic interest. These unusual compounds have so far only been reported from representatives of the subtribe Mutisiinae with the exception of Lycoseris. This latter genus, as well as Aphyllocladus, is placed in subtribe Gochnatiinae $[1,4]$, where sesquiterpene lactones are widespread. However, these compounds are missing in the Mutisiinae. Therefore a reinvestigation of the placement of Lycoseris and Aphyllocladus, both of which contain very similar constituents and are shrubs with secretory canals as in Mutisia [1], may be worthwhile, cspecially since the systematics of this tribe secms still to be a problem [1]. 

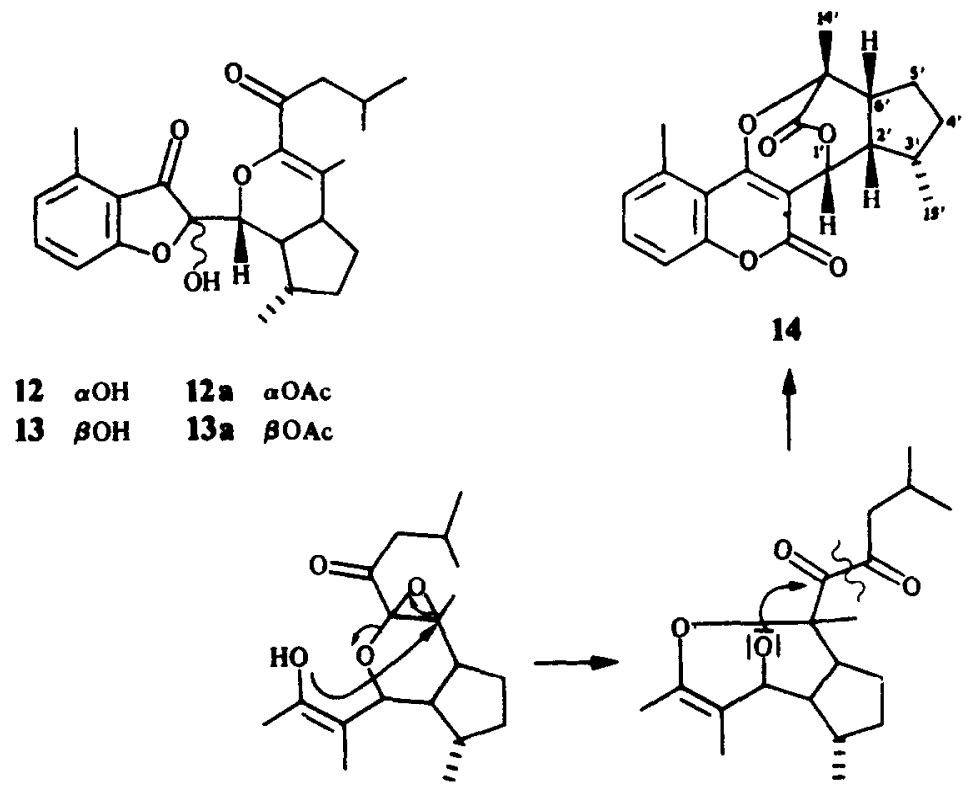

15<smiles></smiles>

$\mathbf{A}$<smiles>[C]#Cc1c(C)cccc1O</smiles>

i.<smiles>C=C1C(=O)Oc2cccc(C)c2C1=O</smiles>

C

\section{EXPERIMENTAL}

The air-dried aerial parts $(560 \mathrm{~g}$, collected E of Puquios, Region de Atacama, Chile, voucher Conc. 72992) were extracted and worked-up as reported previously [5]. CC fractions were combined into four fractions [1: petrol; 2: $\mathrm{Et}_{2} \mathrm{O}$-petrol, (1:9); 3: $\mathrm{Et}_{2} \mathrm{O}$-petrol, $(1: 1) ; 4: \mathrm{Et}_{2} \mathrm{O}$ ]. TLC of fraction 1 (petrol) gave $100 \mathrm{mg} \gamma$-and $20 \mathrm{mg} \delta$-cadinene. Fraction 2 gave $500 \mathrm{mg}$ lupeylacetate and fraction 3 gave by HPLC $\left(\mathrm{MeOH}-\mathrm{H}_{2} \mathrm{O}, 9: 1 ; \mathrm{RP} 8\right.$, flow rate $3 \mathrm{ml} / \mathrm{min}$ in all separations) six fractions $(3 / 1-3 / 6)$. Fraction $3 / 1$ gave after separation by HPLC $2 \mathrm{mg} 11\left(R_{t}\right.$ $1.6 \mathrm{~min}$ ). Fraction $3 / 2$ was separated by TLC ( $\left(\mathrm{Et}_{2} \mathrm{O}\right.$-petrol $\left.1: 1\right)$ affording $15 \mathrm{mg}$ spathulenol and $20 \mathrm{mg}$ of a mixture of 12 and 13 (ca 1:1), which was acetylated $\left(\mathrm{Ac}_{2} \mathrm{O}, \mathrm{CHCl}_{3}, \mathrm{DMAP}, 1 \mathrm{hr} 60^{\circ}\right.$ ) affording 12a/13a. Separation was achieved by TLC [Et ${ }_{2} \mathrm{O}$-petrol (1:9), six developments]. Fraction $3 / 3$ gave by TLC [Et ${ }_{2} \mathrm{O}$-petrol $\left.(1: 3)\right] 10 \mathrm{mg}$ caryophyllenepoxide, $15 \mathrm{mg}$ cadinol T, $3 \mathrm{mg} 10$ and $2 \mathrm{mg} 9$ [purified by HPLC [MeOH- $\left.\mathrm{H}_{2} \mathrm{O}(17: 3), R_{t} 11.0 \mathrm{~min}\right]$. Fraction $3 / 4$ contained $30 \mathrm{mg} 1$, and fraction $3 / 5$ gave by TLC $\left(\mathrm{Et}_{2} \mathrm{O}\right.$-petrol, $\left.1: 3\right) 5 \mathrm{mg} 6$ and $3 \mathrm{mg} 7\left(R_{f} 0.38\right)$. TLC of fraction $3 / 6\left(\mathrm{Et}_{2} \mathrm{O}\right.$-petrol, 1:3) afforded $15 \mathrm{mg} 8$ and $17 \mathrm{mg} 5\left(R_{f} 0.48\right)$. CC of fraction 4 was separated by flash chromatography ( $\mathrm{Si}$ gel, $30-60 \mu$, $\mathrm{Et}_{2} \mathrm{O}$-petrol mixtures) into three fractions $(4 / 1-4 / 3)$. Fraction $4 / 1$ turned out to be inseparable mixture ( ${ }^{1} \mathrm{H}$ NMR showed no acetate methyl) which was acetylated (s.a.). TLC of the acetates $\left(\mathrm{Et}_{2} \mathrm{O}\right.$-petrol, 1:1, two developments) gave $20 \mathrm{mg} 2 \mathrm{a}\left(R_{\boldsymbol{f}} 0.70\right)$, $2 \mathrm{mg} 14\left(R_{f} 0.50\right)$ and $10 \mathrm{mg} 3\left(R_{f} 0.35\right)$. Fraction $4 / 2$ contained a mixture of unidentified triterpenes and fraction $4 / 3$ gave by $\operatorname{TLC}\left(\mathrm{Et}_{2} \mathrm{O}\right) 15 \mathrm{mg} 4\left(R_{f} 0.35\right)$. Known compounds were identi- fied by comparing the $400 \mathrm{MHz}{ }^{1} \mathrm{H}$ NMR spectra with those of authentic material.

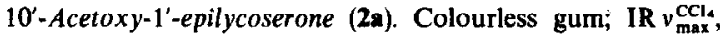
$\mathrm{cm}^{-1}: 3300(\mathrm{OH}), 1730(\mathrm{C}=\mathrm{O}), 1630,1610,1570$ (aromatic); MS

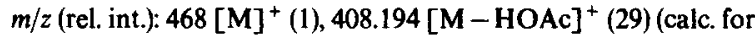
$\left.\mathrm{C}_{25} \mathrm{H}_{28} \mathrm{O}_{3}: 408.194\right), 365\left[408-\mathrm{C}_{3} \mathrm{H}_{7}\right]^{+}(36), 325[408$ $\left.-\mathrm{C}_{4} \mathrm{H}_{7} \mathrm{CO}\right]^{+}(26), 229(44), 189[\mathrm{C}]^{+}(95), 177[\mathrm{~A}]^{+}(48), 135$ $[\mathrm{B}]^{+}(100) ;[\alpha]_{D}^{24^{\circ}}+104\left(\mathrm{CHCl}_{3} ; \mathrm{c} 1.3\right)$.

Isolycoserone (3). Colourless gum; IR $v_{\max }^{\mathrm{CCl}}, \mathrm{cm}^{-1}: 3500-2600$, $1735,1640,1630,1580$ (4-hydroxycoumarin), 1735 (C=O), 1670 $\left(\mathrm{C}=\mathrm{CC}=\mathrm{O}\right.$ ); $\mathrm{MS} \mathrm{m} / \mathrm{z}$ (rel. int.): $410.210[\mathrm{M}]^{+}$(8) (calc. for $\left.\mathrm{C}_{25} \mathrm{H}_{30} \mathrm{O}_{5}: 410 . .209\right), 396\left[\mathrm{M}-\mathrm{H}_{2} \mathrm{O}\right]^{+}(4.5), 323(8), 222$ (44), $221(40), 204(100), 189[\mathrm{C}]^{+}(51), 135[\mathrm{~B}]^{+}(57) ;[\alpha]_{\mathrm{D}}^{24}-21$ $\left(\mathrm{CHCl}_{3} ; c 0.42\right)$.

10-Hydroxyisolycoserone (4) Colourless gum, IR $\nu_{\max }^{\mathrm{CCl}_{4}}, \mathrm{~cm}^{-1}$. $3500-2600,1730,1640,1620,1570$ (hydroxycoumarin); 1670 $\left(\mathrm{C}=\mathrm{CC}=\mathrm{O}\right.$ ); $\mathrm{MS} m / z$ (rel. int.). $426.204[\mathrm{M}]^{+}$(1.3) (calc. for $\left.\mathrm{C}_{25} \mathrm{H}_{30} \mathrm{O}_{6}: 426.204\right), 354[\mathrm{M}-\mathrm{OCHCHMe}]^{+}(20), 248$ (20), $189(40), 177[\mathrm{~A}]^{+}(100), 135[\mathrm{~B}]^{+}(66) ;{ }^{13} \mathrm{CNMR}\left(\mathrm{CDCl}_{3}\right) \mathrm{C}$ 2-C-9: $\delta 166.7 s, 100.1 s, 164.4 s, 115.1 s, 138.1 s, 127.4 d, 130.8 d$, $114.5 d, 154.0 \mathrm{~s}, 21.9 q ; \mathrm{C}-1^{\prime}-\mathrm{C}-15^{\prime}: 32.9 t, 61.8 \mathrm{~s}, 29.9 t, 27.2 t$ $26.4 t, 184.7 s, 130.3 s, 206.0 s, 86.8 s, 78.3 d, 37.4 d, 14.9 q, 14.1 q$, $8.5 q, 23.5 q$. Acetylation $\left(\mathrm{Ac}_{2} \mathrm{O}, 1 \mathrm{hr}, 70^{\circ}\right)$ gave $4 \mathrm{a}$; colourless gum; IR $v_{\max }^{\mathrm{CCl}_{4}}, \mathrm{~cm}^{-1}: 3520(\mathrm{OH}), 1785(\mathrm{C}=\mathrm{C}-\mathrm{OAC}), 1730(\mathrm{C}=\mathrm{O}$, $\mathrm{OAc}$ ); $\mathrm{MS} m / z$ (rel. int.): $510.225[\mathrm{M}]^{+}$(1) (calc. for $\mathrm{C}_{29} \mathrm{H}_{34} \mathrm{O}_{8}$ : $510.225), 450[\mathrm{M}-\text { ketene }]^{+}(5.5), 390\left[450-\mathrm{HOAc}^{+}(2.5), 262\right.$ (28), $220(100), 219(88), 177[\mathrm{~A}]^{+}(36), 135[\mathrm{~B}]^{+}(26)$.

$1^{\prime}, 2^{\prime}, 6^{\prime}, 7^{\prime}, 8^{\prime}$-Epicyclolycoserone (5). Colourless gum; IR $v_{\max }^{\mathrm{Cl}_{4}}, \mathrm{~cm}^{-1}: 1730(\mathrm{C}=\mathrm{O}), 1720,1630,1605$ (coumarin); MS 


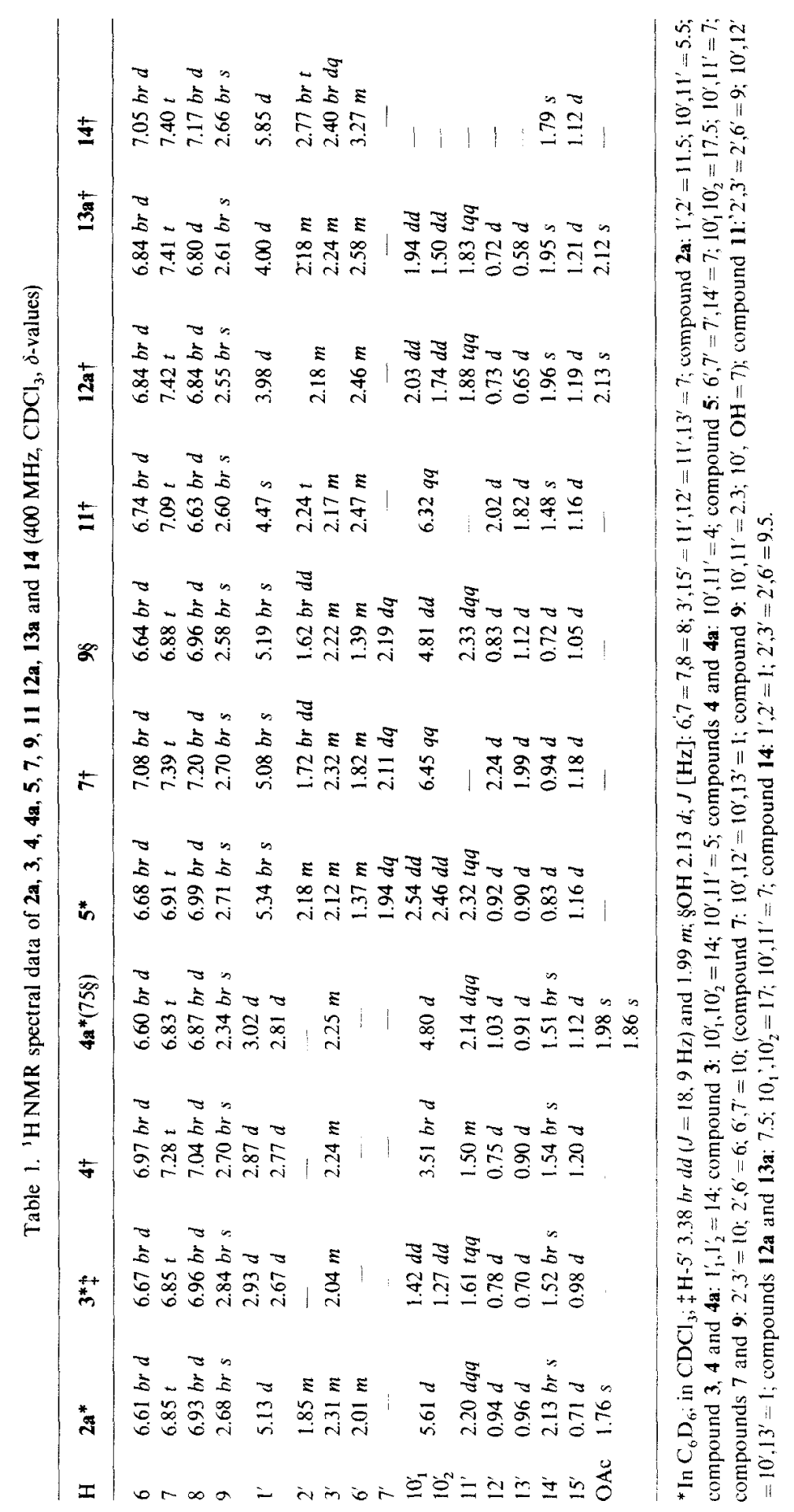


$m / z$ (rel. int.): 410.209 [M] ${ }^{+}$(10) (calc. for $\mathrm{C}_{25} \mathrm{H}_{30} \mathrm{O}_{5}: 410.209$ ), $392\left[\mathrm{M}-\mathrm{H}_{2} \mathrm{O}\right]^{+}(2), 326\left[\mathrm{M}-\mathrm{C}_{5} \mathrm{H}_{8} \mathrm{O}\right]^{+}(36), 325[\mathrm{M}$ $\left.-\mathrm{COCH}_{2} \mathrm{CHMe}_{2}\right]^{+}(56), 308\left[326-\mathrm{H}_{2} \mathrm{O}\right]^{+}(58), 189[\mathrm{C}]^{+}$ (100), $135[\mathrm{~B}]^{+}(84) ;[\alpha]_{\mathrm{D}}^{24^{\circ}}-78\left(\mathrm{CHCl}_{3} ; c\right.$ 1.62).

$10^{\prime}, 11^{\prime}$-Dehydrocyclolycoserone (7). Colourless gum; IR $v_{\max }^{\mathrm{CCl}}, \mathrm{cm}^{-1}: 1710$ (coumarin, $\mathrm{C}=\mathrm{CC}=\mathrm{O}$ ); $\mathrm{MS} \mathrm{m} / z$ (rel. int): $408.194[\mathrm{M}]^{+}$(6.4) (calc. for $\mathrm{C}_{25} \mathrm{H}_{28} \mathrm{O}_{5}: 408.194$ ), $326[\mathrm{M}$ $\left.-\mathrm{C}_{5} \mathrm{H}_{6} \mathrm{O}\right]^{+}(2), 325\left[\mathrm{M}-\mathrm{C}_{5} \mathrm{H}_{7} \mathrm{O}\right]^{+}(6), 308\left[326-\mathrm{H}_{2} \mathrm{O}\right]^{+}(24)$, $189[\mathrm{C}]^{+}(12), 135[\mathrm{~B}]^{+}(14), 83\left[\mathrm{C}_{4} \mathrm{H}_{7} \mathrm{CO}\right]^{+}(100)$.

$10^{\prime}$-Hydroxycyclolycoserone (9). Colourless gum; IR $v_{\max }^{\mathrm{Cll}}, \mathrm{cm}^{-1}: 3500(\mathrm{OH}), 1720,1625,1600$ (coumarin), 1720 (C=O); MS m/z (rel. int.): $426.204[\mathrm{M}]^{+}(12)$ (calc. for $\mathrm{C}_{25} \mathrm{H}_{30} \mathrm{O}_{6}$ : 426.204), $326\left[\mathrm{M}-\mathrm{C}_{5} \mathrm{H}_{8} \mathrm{O}_{2}\right]^{+}(42), 325\left[\mathrm{M}-\mathrm{C}_{5} \mathrm{H}_{9} \mathrm{O}_{2}\right]^{+}(52)$, $308\left[326-\mathrm{H}_{2} \mathrm{O}\right]^{+}(7), 246(73), 189[\mathrm{C}]^{+}(100), 177\lfloor\mathrm{~A}]^{+}(11)$, $135[\mathrm{~B}]^{+}(76)$.

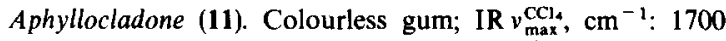
$\left(\mathrm{C}=\mathrm{CC}=\mathrm{O}\right.$ ); $\mathrm{MS} \mathrm{m} / \mathrm{z}$ (rel. int.): $396.194[\mathrm{M}]^{+}(10)$ (calc. for $\left.\mathrm{C}_{24} \mathrm{H}_{28} \mathrm{O}_{5}: 396.194\right), 233$ (28), $177[\mathrm{~A}]^{+}(8), 135[\mathrm{~B}]^{+}(34), 83$ $\left[\mathrm{C}_{4} \mathrm{H}_{7} \mathrm{CO}\right]^{+}(100)$.

3-Acetoxycoumarolycoserone (13a). Colourless gum; MS $\mathrm{m} / \mathrm{z}$ (rel. int.): $440.220[\mathrm{M}]^{+}$(35) (calc. for $\mathrm{C}_{26} \mathrm{H}_{32} \mathrm{O}_{6}: 440.220$ ), 380 $\left[\mathrm{M}-\mathrm{HOAc}^{+}(5), 296(76), 295\left[380-\mathrm{C}_{5} \mathrm{H}_{9} \mathrm{O}\right]^{+}(100), 235(60)\right.$, 175 (26), 161 (38), 137 (43), 136 (62), 135 (50), 91 (58); ${ }^{13}$ C NMR
$\left(\mathrm{CDCl}_{3}\right) \mathrm{C}-3-\mathrm{C}-9: \delta 101.8 s, 196.9 s, 119.7 s, 138.9 s, 124.0 d, 137.0$ $d, 109.3 d, 142.8 s, 22.2 q ; \mathrm{C}-1^{\prime}-\mathrm{C}-15^{\prime}: \delta 76.2 d, 43.1 d, 36.8 d, 33.9 t$, $31.5 t, 43.0 d, 167.5 s, 124.1 s, 198.2 s, 47.5 t, 22.3 d, 17.8 q, 17.0 q$, $22.2 q, 23.2 q$; OAc: $\delta 20.5 q, 170.1 \mathrm{~s}$.

Aphyllodenticulide (14). Colourless crystals, mp 221-223 $\left(\mathrm{Et}_{2} \mathrm{O}\right.$ ); IR $v_{\max }^{\mathrm{CCl}_{4}}, \mathrm{~cm}^{-1}: 1760$ (lactone), 1715, 1620, 1610 (coumarin); MS $m / z$ (rel. int.). $340.131[\mathrm{M}]^{+}(100)$ (calc. for $\mathrm{C}_{20} \mathrm{H}_{20} \mathrm{O}_{5}$ : $340.131), 214\left[\mathrm{M}-\mathrm{C}_{7} \mathrm{H}_{10} \mathrm{O}_{2}\right]^{+}(93), 190(82), 189[214-\mathrm{Me}]^{+}$ $(67), 135[\mathrm{~B}]^{+}(70), 107[135-\mathrm{CO}]^{+}(54)$.

Acknowledgement - $\mathrm{H}$. M. N. is indebted to the Alexander von Humboldt-Stiftung for a research fellowship.

\section{REFERENCES}

1. Cabrera, A. (1977) The Biology and Chemistry of the Compositae (Heywood, V. H., Harborne, J. B. and Turner, B. L., eds), p. 1042. Academic Press, London.

2. Bohlmann, F., Jakupovic, J., Misra, L. N. and Castro, V. (1985) Liebigs Ann. Chem. 1367.

3. Kuhnke, J. (1988) Ph.D. thesis, Technical University Berlin.

4. Cabrera, A. (1961) Mus. Argent. Cienc. Nat. Bot. 2, 291.

5. Zdero, C., Bohlmann, F. and Niemeyer, H. M. (1988) J. Nat. Prod. (in press). 